\title{
前頭葉損傷患者に標準意欲評価法を用いた 自発性低下の評価
}

\section{一日常生活行動の意欲評価スケールにおける家族と看護師の評価の特徵一}

\author{
The Evaluation of Apathy by Using the Scale of Clinical Assessment for Spontaneity: \\ Characteristics of Evaluation between Families and Nurses
}

\author{
小浜さつき ${ }^{*}$, 日高艶子，松尾ミヨ子 \\ Satsuki Obama, Tsuyako Hidaka, Miyoko Matsuo
}

キーワード : 自発性低下, 家族, 評価, 前頭葉機能障害

Key words : apathy, families, evaluation, frontal lobe dysfunction

\begin{abstract}
Purpose: Apathy is one kind of frontal lobe dysfunction, and patients who suffer from apathy tend to be misdiagnosed as being "lazy" by medical staff and families. Recently, apathy-measuring scales have been developed, such as the "Clinical Assessment for Spontaneity (CAS)" to try to evaluate this disability as objectively as possible. CAS consisted of five subscales to measure multiple viewpoints of apathy. In this study we used the CAS3, the scale for assessment of spontaneity about patients' ADL. The purpose of this study was to investigate the characteristics of evaluation between families and nurses in assessing patients' apathy.

Method: Thirty-nine pairs of families and nurses were interviewed and evaluated concerning patients' apathy using the CAS3 scale.

Results: A significant correlation was observed between the total CAS scores of families and nurses. However, the subscale CAS3 scores for specific categories, especially "grooming," "bathing," "medication," "greeting," "communication with others," and "hobbies" did not correlate significantly.

Conclusion: When the results of CAS3 were analyzed, the total score of CAS was correlated, but there were evaluation gaps between nurses and families for some items because of the difference of observation opportunities. These results suggest that if families participate in patients' assessment, nurses can evaluate apathy in more detail based on information about patients' characteristics and lifestyles before a stroke occurs.
\end{abstract}

\section{要旨}

目的：前頭葉損傷に伴う自発性低下は，近年，標準意欲評価法（Clinical Assessment for Spontaneity, CAS）が開発され，客観的評価が試みられる。本研究では, CAS の 5 つの尺度の中でも, 特に

受付日：2013 年 5 月 13 日 受理日 : 2014 年 2 月 13 日

聖マリア学院大学看護学部看護学科 St. Mary's College School of Nursing

*E-mail : obama@st-mary.ac.jp 
看護師が評価に関わる可能性が高い日常生活行動の意欲評価スケール（以下 CAS3）に着目し, 看護 師と家族の両者の評価について相違点や一致内容を検討することを目的とした。

方法：前頭葉損傷患者の家族, 看護師各 39 名が, 患者の自発性を評価した。自発性の測定には CAS3 を用いた.

結果 : 看護師と家族の評価結果は CAS3 の合計得点において，類似した回答結果を示した。しかし， 洗面, 入浴, 服薬，挨拶，会話，趣味では，回答が異なる傾向を認めた.

結論 : 看護師と家族間の日常生活行動における自発性低下の評価が異なる要因には, 観察機会の差 があると推測された。評価の妥当性を高めるためには，看護師と家族両者の評価を検討する必要があ ることが示唆された。

\section{I 。緒言}

脳血管障害患者の前頭葉損傷に伴う自発性低下の 発症頻度は，約 26.7〜 40\% と報告されている（Brodaty et al., 2005; Hama et al., 2007).

前頭葉損傷に伴う自発性低下は, 研究者により「意 欲の低下」,「発動性低下」等, 病態の定義に差があ るが, 大東 (2008) は, 「意欲の方は原則として心理 的側面を捉えようとしているのに対し，発動性とい うのは身体的側面をも含む心身生命過程における駆 動力という意味合いを有しており， $\cdots$ (中略) 自発性 の障害という場合には, 意欲の障害も発動性の障害 も，ともに含みえるような病態を想定していること になる」としている.

自発性低下が問題視されるのは，医療者によって 十分な評価がなされることなく，「単なる性格変化」 または「急惰である」と誤解され, 改善する可能性 があるのに放置されることである（布谷ら，1994）。

自発性低下の評価尺度開発は，米国の Marin ら （1991）によって始まったとされる. Marin ら (1991) は, 自発性低下の評価は, 患者, 医療者, 家族の三 者で評価することの必要性を論じている，Marin ら （1991）によると，患者は, 脳損傷により認知機能 障害を呈していることから評価の妥当性は乏しいが, 家族は, 自宅で観察した患者の生活行動に基づく評 価を行うことが可能であり，医療者の評価を補完す ることができると述べている.

一方，わが国においては，2006 年に日本高次脳機 能障害学会により標準意欲評価法 (Clinical Assessment for Spontaneity; 以下CAS) が開発された. CAS は, 定量的測定が簡単でない自発性低下につい て，1．面接による直接的評価，2，質問紙による自 覚的な意欲評価，3．日常生活行動面での意欲評価，4. 自由時間の行動観察，5. 総合評価といった多面的な 視点で，可能な限り定量的に重症度を測定すること
を目的とし開発され (加藤, 2006), 臨床での評価へ の活用が広まりつつある。CAS の評価は，医療者と 患者により評価できるように構成されているが，日 常生活や自由時間の評価については, 医療者が家族 に対しても聞き取り調查を実施し，家族の観察に基 づいて評価する（日本高次脳機能障害学会，2006） とある。つまり, 医療者が行う自発性低下の評価に 家族の評価を加味することが期待されていると考元 ることができる。しかし，家族がいかに評価に参入 するかについては，明確には示されていない.

他者から「意欲がない」と誤解されやすいと指摘 される自発性低下の特徵を考慮すると, 発症前の患 者の生活状況や病前の性格を知らない医療者による 評価には, 自発性低下の過大評価, 過小評価の可能 性が推測される。

事実，看護師が，「自発性低下がない」と判断し ても，家族は「発症前はもっと几帳面な人であった， やる気がない」と評価し両者の評価が異なる場合が ある。このような場合, 家族と医療者が意見を交換 しなければ，医療者は患者の自発性低下を問題視せ ず介入の必要性を認識しないまま経過してしまう可 能性がある。そのため, 看護師は, 前頭葉損傷の病 態を理解し専門的な視点で行動を観察し, 自発性の 低下を評価するとともに, 発症前の患者の生活習慣 や性格を知る家族の評価を十分に検討する必要があ ると考える。

そこで, 本研究では看護師と家族両者による自発 性低下についての妥当性の高い看護アセスメント方 法の確立を目指し, CASの 5 尺度の中でも, 特に 看護師が評価に関わる可能性が高いCAS3 に着目し, 看護師と家族間の評価の相違点や一致内容を検討す ることを目的とした。本研究により, 自発性低下の 評価における看護師と家族間の評価の特徵が明らか になれば，自発性低下の評価に家族が参入すべき項 目が明示され, 評価の精度を高めるための示唆を得 
ることが期待される。

\section{II . 用語の定義}

本研究では, 大東 (2008) の定義に従い, 自発性 低下を「外部からの刺激には最小限応じるが, 意識・ 情動・認知に大きな障害がないにもかかわらず, 個 体自身からの自発的な賦活が認められず，かつ外界 で生じていることに対し根本的に無関心である状態」 と定義する。

\section{III. 研 究方法}

\section{1. 研究対象の選定}

自発性低下は, 高次脳機能障害の中でも看護の先 行研究が少ないという現状から, 看護師の認知度が 低いことが推測された。そこで, 研究依頼施設には 高次脳機能障害患者のリハビリテーション看護研究 に取り組む 2 施設を選定した。まず，研究依頼施設 の看護管理者に対し, 調査依頼期間に入院中の全患 者のうち選定基準に該当する患者の抽出を依頼した， その後, 評価対象者となる患者, 評価者となる患者 の家族, 看護師の 3 名を 1 組とした。合計 41 組に依 頼し，2 組から同意が得られず，39組（計 117 名） を研究対象とした。対象の選定基準を以下に示す。

1）患者の選定基準：(1) 自発性低下の責任病巣で ある前頭葉, 前頭葉との関連が報告される視床, 基 底核の損傷を呈し, 病状が安定している者。（2）重 度の失語症や認知症を呈さず，意思疎通が可能な者. (3) 運動麻痺等の身体機能障害や他の高次脳機能 障害による評価への影響を可能な限り除外するため, セルフケアが見守りから一部介助の者とした。

2）家族の選定基準 : 発症前の患者の性格や生活状 況をよく知る者で，認知症の既往がないこととした， 家族が複数名いる場合は, 患者のキーパーソンで発 症前に患者と同居していた者とした，面会頻度が低 い家族（週 2 回以下）に対しては，家族の中でも患 者のセルフケア状況を最もよく知る者を選定した。

3）看護師の選定基準：回復期リハビリテーション 病棟における患者の受け持ち看護師であり, 高次脳 機能障害患者の評価能力の基準として, 脳血管障害 患者の看護経験 3 年以上, 臨床経験年数 5 年以上と した。看護師が選定基準に達しない場合, 経験年数 の高い看護師に評価への同席を依頼し，不明な点を
相談できるように配慮した上で受け持ち看護師が患 者評価を行つた。

\section{2. 調査内容}

\section{1）評価対象となる患者の個人属性}

患者の個人属性は, 年齢, 性別, 医学診断名, 脳 血管障害の発症日, 回復期リハビリテーション病棟 転入後の期間, 脳の損傷半球と損傷部位, 高次脳機 能障害評価, 機能的自立度評価法 (Functional Independence Measure: 以下 FIM), Mini Mental State Examination（以下 MMSE）の得点とした。

\section{2）評価者となる家族と看護師の個人属性}

家族の個人属性は，年齢，性別，評価対象患者と の続柄（配偶者, 子供, その他) とした。また, 家 族の評価に影響を与えると推測された面会頻度（毎 日，一週間に 2 回以上，一週間に 1 回), 面会時間の 長さ (30 分から 1 時間, 1 時間以上), 看護師との関 係（何でも相談できる, 時々相談する, あまり相談し ない)について尋ねた。看護師の個人属性は, 看護師 臨床経験年数 (3 から 5 年, 5 年以上), 脳血管障害患 者の看護経験年数 (3 年未満, 3 から 5 年以上), 自 発性低下の患者の看護経験 (有, 無), 自発性低下の 尺度活用経験 (有, 無), 尺度使用経験がある者には, 使用した尺度名について尋ねた。

\section{3. 測定用具}

\section{1）対象患者の自発性低下の評価}

本研究では, 看護師と家族が対象患者の自発性低 下を評価する尺度として CAS の 5 つのサブスケール の中でも, CAS3 を使用した. CAS3 は, 従来から活 用されてきた自発性低下の評価尺度の中から意欲状 態を評価するに妥当であり，かつできるだけ共通し た 16 の行動項目を選定して作成された. 16 の行動項 目は，（1）食事をする，（2）排泄の一連の動作を行う, （3）洗面・歯磨きをする，(4) 衣服の着脱をする，(5) 入浴を行う，(6) 訓練を行う，(7) 服薬をする，(8)テ レビを見る，(9) 新聞または雑誌を読む，(10）他者と 挨拶をする，(11）他者と話をする，(12）電話をする, （13）手紙を書く, (14) 行事に参加する, (15) 趣味を 行う，(16）問題解決可能, である. 評価基準は, 「0: ほぼいつも自発的に行動できる」,「1：いつも自発 的とは限らず，ときに何かの促しや手助けが必要で, 促されれば行動できる」,「2：ほぼいつも何らかの促 
しや手助けが必要で，促されれば行動できる」，「3： 促しや手助けがあってもいつも行動できるわけでは なく，行動しないこともある」，「4:多くの場合促 しや手助けがあっても行動しない」の 5 段階評価で, 得点範囲は 0-64 点, 得点が高いほど自発性低下が重 度である。ただし，合計得点の算出については，項 目によって病前の習慣がない等, 該当する行動の意 欲評価が不可能な場合は，\% 評価值 $\{$ 合計得点 $\div$ (評 価可能であった項目数 $\times 4) \times 100\}$ として得点を算出す る(日本高次脳機能障害学会, 2006)。CAS3 が医療 者向けの評価尺度であることを踏まえ, 評価困難で ある場合は「5：評価できない」とし，その理由を尋 ねた。本研究における CAS3 の信頼性は家族の回答 結果の $\alpha$ 係数が 0.885 であった。看護師の CAS3 の $\alpha$ 係数は, 全項目が回答可能な人数が少なく, 算出 が不可能であった。

\section{2）評価対象となる患者の，日常生活機能の評価}

患者の日常生活機能の評価にはFIMを用いた。 FIM は 1984 年に米国で医学的リハビリテーション のための統一的データシステムを開発することを目 的として Keith et al.（1987）により報告され（水野 ら，2005），わが国では千野（1991）によって邦訳さ れ，FIM ガイドブックの日本語版が出版された（千 野ら，1997)。FIM は，リハビリテーション領域で活 用される日常生活行動の自立評価尺度で, 得点範囲 は 0 から 126 点, 得点が高いほど自立度が高い。本 研究対象における $\alpha$ 係数は 0.943 であった. FIM は 受け持ち看護師の評価結果を看護記録より収集した。

\section{3）評価対象となる患者の，認知機能の評価}

患者の認知機能の評価は, Folstein et al. (1975) が開発し, 森ら（1985）によって日本語版が作成さ れた Mini-Mental State Examination (MMSE) を 用いた. MMSE は, 見当識, 記銘, 注意と計算, 再生, 言語の 5 領域から構成され, 得点範囲は 0 点 30 点 である。本研究では担当作業療法士の評価結果を診 療録より収集した。

\section{4. 調查方法}

調査は，家族，看護師，患者の順に実施した。1 組の調査期間は，時間的変化による評価への影響を 防ぐため 1 週間以内とした。家族と看護師の調査は, 許可を得た上で都合のよい時間に実施した。調査は,
30 分から 40 分の構成化面接法とし個室で実施した. 調査期間は 2009 年 6 月〜 11 月であった。

\section{5. 分析方法}

各デー夕は, Kolmogorov-Smirnov の正規性の検 定を実施し，正規性が確認されない場合，ノンパラメ トリックな手法を用いた。家族と看護師の評価差は, Mann-Whitney U 検定による差の検定を実施し，尺 度間の関係や家族と看護師の評価の関係は Spearman の順位相関係数により分析した。評価者間一致度を 示す $\kappa$ 係数は，正規分布を認めず本研究では算出し なかった。また, 評価不可の項目については, 発言 内容を集計した。統計学的検定の有意水準は $p<0.05$ とし，SPSS 統計パッケージVer.17.0を用いた。

\section{6. 倫理的配慮}

大阪府立大学看護学研究科倫理審査委員会の承認 を得た (承認番号 21-9) 後, 調査依頼施設 (2 施設) の倫理審査委員会の承認を得た。研究目的や個人情 報保護, 人権擁護等の倫理的配慮について, 同意書 の署名により同意を確認した。

\section{N. 結 果}

\section{1. 対象の属性（表 1）}

患者は平均年齢が 67 歳, 脳出血が 17 名 $(43.6 \%)$, 脳梗塞が 15 名 (38.5\%) であった。発症からの期間 は中央値が 113 日, 回復期病棟入院期間は, 中央值 が72日であった。高次脳機能障害評価において,「自 発性低下」「発動性低下」「意欲の低下」と記録され た患者は 8 名 (20.5\%) であった。 MMSE の得点は 10 点〜30 点とばらつきを認めたが, MMSE 得点が 低い患者については, 自発性低下のために質問に意 欲的に回答ができないものが含まれ, 認知症と評価 された患者は認めなかった。家族は平均年齢が 58 歳, 女性が 7 割以上を占め, 続柄は配偶者が多く発症前 に患者と同居していた家族が 8 割以上であった。看 護師は, 38 名が経験年数 5 年以上で, 全員自発性低 下の患者の看護経験を持つが, 自発性低下の尺度を 使用した評価の経験のあるものは 3 割であった。

\section{2. 家族と看護師の自発性低下の評価結果 1）家族と看護師の CAS3 の \% 評価值の差異}

$\mathrm{CAS3}$ の \% 評価值は, 家族の回答が $15.0 \pm 13.3$, 看 
表 1 対象の属性

\begin{tabular}{|c|c|c|c|}
\hline & 項 目 & & \\
\hline \multirow[t]{24}{*}{ 患者 $(n=39)$} & 年齢 § & & 67 (28-88) \\
\hline & 性別 \$ & 男性 & 20 (51.3) \\
\hline & & 女性 & $19(48.7)$ \\
\hline & 発症期間 $\left(\right.$ 日) ${ }^{\S}$ & & 113 (57-208) \\
\hline & 回復期期間 $(日) \S$ & & 72 (28-164) \\
\hline & 医学診断名 $\$$ & 脳出血 & $17(43.6)$ \\
\hline & & 脳梗塞 & $15(38.5)$ \\
\hline & & <も膜下出血 & $4(10.3)$ \\
\hline & & 頭部外傷 & $3(7.6)$ \\
\hline & 損傷半球 $\$$ & 右 & 11 (28.2) \\
\hline & & 左 & $13(33.3)$ \\
\hline & & 両側 & $15(38.5)$ \\
\hline & 損傷部位 $\$$ 9 & 前頭葉 & $18(46.2)$ \\
\hline & & 基底核 & $26(66.7)$ \\
\hline & & 視床 & $9(23.1)$ \\
\hline & きき手\$ & 右 & $39(100)$ \\
\hline & 筋力低下 $(M M T)^{\$}$ & 右 & $12(30.8)$ \\
\hline & $(n=38)$ & 左 & $17(43.6)$ \\
\hline & & 両側 & $9(23.1)$ \\
\hline & $\mathrm{FIM}^{\dagger}$ & 合計 & $85 \pm 21.7$ \\
\hline & $\operatorname{MMSE}(n=36)^{* \S}$ & & $23.5(10-30)$ \\
\hline & 高次脳機能障害 & 自発性低下 & $8(20.5)$ \\
\hline & 評価 $\$$ 凤 & 注意障害 & $33(84.6)$ \\
\hline & & 言語障害 & $18(46.2)$ \\
\hline \multirow[t]{15}{*}{ 家族 $(n=39)$} & 年齢 § & & $58(40-83)$ \\
\hline & 性別 \$ & 男性 & $9(23.1)$ \\
\hline & & 女性 & $30(76.9)$ \\
\hline & 続柄 \$ & 配偶者 & $29(74.4)$ \\
\hline & & 配偶者以外 & $10(25.6)$ \\
\hline & 同居の状況 ${ }^{\text {\$ }}$ & 同居 & $33(84.6)$ \\
\hline & & 別居 & $6(15.4)$ \\
\hline & 面会頻度 $\$$ & 毎日 & २2 (56.4) \\
\hline & & 週二回以上 & $14(35.9)$ \\
\hline & & 週一回 & $3(7.7)$ \\
\hline & 面会時間 \$ & 0.5 1 時間 & $10(25.6)$ \\
\hline & & 1 時間以上 & $29(74.4)$ \\
\hline & 看護師との関係 \$ & 何でも相談 & $14(35.9)$ \\
\hline & & 時々相談 & $7(17.9)$ \\
\hline & & 相談しない & $18(46.2)$ \\
\hline \multirow[t]{10}{*}{ 看護師（ $n=39 ）$} & 看護師経験年数 $\$$ & 3 年 $~ 5$ 年 & $1(2.6)$ \\
\hline & & 5 年以上 & $38(97.4)$ \\
\hline & 脳血管障害患者の看護経験年数 $\$$ & 3 年未満 & $4(10.3)$ \\
\hline & & $3 \sim 5$ 年以上 & $35(89.7)$ \\
\hline & 自発性低下患者の看護経験 $\$$ & ある & $39(100)$ \\
\hline & 尺度活用経験 \$ & ある & $14(35.9)$ \\
\hline & & ない & $25(64.1)$ \\
\hline & 使用した尺度 & S-Score & $13(92.9)$ \\
\hline & $(n=14, \text { 複数回答 })^{\$ \ddagger}$ & やる気スコア & $3(21.4)$ \\
\hline & & W-Sスケール & $2(14.3)$ \\
\hline
\end{tabular}

注) § 中央值 (範囲)，\$人数 (\%), †平均土 SD *MMSE: 3 名は失語により評価不可. ๆ 診療録やリ八ビリテーション部の評価に「自発性低下」, 「発動性低下」と記載されていたものを「自発性低下あり」とし, 人数を集計した。 † S-Score (涌井ら, 1993), やる気スコア (岡田ら, 1998), W-S スケール (窪田ら, 2001).

護師の回答が $18.4 \pm 16.4$ であり，2 者間に統計学的有 意差を認めなかった $(p=0.429)$ 。また, CAS3 のカッ トオフ值は 1 点と報告されるが (日本高次脳機能障害 学会，2006），本調査において，家族と看護師から自
発性低下がない，つまり CAS3 の評価が 0 点と評価 された患者は，看護師と家族両群ともに 5 名であった。 
2）家族と看護師の CAS3 の\% 評価値の相関と FIM, MMSE の関係

家族と看護師の CAS3 の評価は，\%評価值において。 $760(p<0.01)$ と正相関を認めた。 FIM と CAS3 の \% 評価値の相関は, 家族評価が $-.723(p<0.01)$, 看護 師評価がー.858 $(p<0.01)$ と負の相関を示し, MMSE と CAS3 は, 家族評価が $-.765(p<0.01)$, 看護師評 価がー.691（p<0.01）であった。

\section{3）家族と看護師の 16 評価項目別回答結果の相関 と評価の特徵（表 2)}

CAS3 の 16 評価項目の中で家族と看護師の回答に 有意相関を認めなかった項目は「洗面・歯磨き」「入 浴」「服薬」「あいさつ」「他者と話をする」「趣味活 動」の 6 項目であった。また, CAS3 の評価項目の 中で家族と看護師が「評価不可」と回答した人数と その理由を表 2 に示した。セルフケアにおける評価 は看護師全員評価可能であるのに対し，家族は「観 察機会がない」という理由で評価不可の者が多かった。 特に入浴は 18 名 (46.2\%) の家族が観察機会なしと回 答した。一方，新聞を読む，電話をする等の項目には， 看護師が評価不可と回答した者が多かった。

\section{V. 考 察}

\section{1. 対象群の特性}

評価対象となった患者の自発性について，診療録 に自発性低下があると記載された患者は 8 名と少数 であったが, CAS3 が 0 点, つまり自発性低下がな いと評価されたのは看護師，家族ともに 5 名と限ら れ，34 名の患者には日常生活場面において何らかの 自発性低下が認められた。この結果から, CAS3 を 用いた日常生活の詳細な観察を行うことで，ごく軽 度な症状であっても発見につながる事例があること が推測された。また，評価者となった家族は，面会 時間が長く, 患者の病棟生活状況をよく知る家族が 多く対象に含まれた。さらに，評価者となった看護 師は，自発性低下の患者の看護経験があると回答し たが，尺度を使用した経験のあるものは 14 名と限ら れた。本研究を依頼した 2 施設の回復期リハビリテー ション病棟は, いずれも高次脳機能障害患者の看護 研究に取り組む施設であり, 高次脳機能障害患者に 対する看護師の知識は，一般病院に比較して高いと 推測された。しかし，本調査結果からは，定量的な
評価を目的とし開発された尺度の使用率は低く，自 発性低下の評価について, 看護師個々の主観による 評価がなされている可能性が高いことが示された。

\section{2. 家族と看護師の自発性低下に関する評価の特徵}

自発性低下の評価に限らず，脳卒中患者の認知機 能の評価が困難であることは, 多くの先行研究にお いて分析され，患者自身の主観的評価，医療者や家 族の客観的評価の両者に，何らかの問題があると報 告される (Williams et al., 2002; Østbye et al., 1997). 例えば，患者自身は，脳卒中を発症後の認知機能や 言語機能障害の影響により，自己の認知機能につい て適切な評価が困難になる (Malec et al., 1997; Chen et al., 2007）と指摘さ机る。また，家族による患者評 価では，脳卒中に対する知識がそしいこと，回復へ の過度の期待を抱きやすいと報告され，さらに医療 者は発症前の患者の性格を知らないため，患者の認 知機能障害を過大・過小評価する傾向があると報告 される (Williams et al., 2002; Østbye et al., 1997).

本研究の結果からは, CAS3 の \% 評価值には家族 と看護師間に統計学的な有意差を認めず，両者が類 似した評価を行っていた。しかし，CAS3 の項目を 見ると洗面・歯磨き，入浴，服薬，あいさつ，話を する，趣味の 6 項目では，評価が異なる傾向を示した， また，評価不可の項目を見ると，洗面・歯磨き，入浴， 服薬の 3 項目は，「観察機会がない」と回答した家族 が多かった。これは，先行研究で指摘される医療者 と家族の評価差に影響する要因のうち，観察機会の 差（Malec et al., 1997）の影響と考えられた。 反対に, 新聞を読む，手紙を書く等は，発症前にその行為の 習慣があるかを踏まえて，看護師より家族の方が詳 細な評価が可能であった。以上より，入浴や服薬等 の面会時の観察機会が限られる行為には，看護師が 家族に観察の結果を伝えることが望ましく，一方病 棟で観察機会が少ない新聞や手紙を書く等の活動は, 家族の評価を参考にすることで，医療者の過大評価 の予防が可能と推測された。

また，挨拶や話をするというコミュニケーション に関連する項目については，家族と看護師の相関が 低かったが，これは医療者に比較して家族の方が患 者自身の動因が高い，つまり患者自身が相手と話し たいという欲求が強いことが影響すると推測される。 そのため, コミュニケーションに対する患者の自発 性の評価について，医療者は，家族に対し面会時の 
表 2 CAS3 の 16 評価項目にみる家族と看護師の評価結果の相関と評価の特徵

\begin{tabular}{|c|c|c|c|c|c|}
\hline \multirow{2}{*}{$\begin{array}{l}\text { CAS3 } \\
\text { 項 目 }\end{array}$} & \multirow{2}{*}{ 項目別相関係数 } & \multicolumn{2}{|r|}{ 家族 } & \multicolumn{2}{|r|}{ 看護師 } \\
\hline & & 評価不可 § & 評価が不可能な理由 & 評価不可 § & 評価が不可能な理由 \\
\hline 食事 & $.479 * *$ & $1(2.6)$ & 観察機会なし & $0(0)$ & 評価不可なし \\
\hline 排泄 & $.362^{*}$ & $2(5.1)$ & 観察機会なし & $0(0)$ & 評価不可なし \\
\hline 洗面 & $.163 \mathrm{~ns}$ & $1(2.6)$ & 観察機会なし & $0(0)$ & 評価不可なし \\
\hline 更衣 & $.659^{* *}$ & $5(12.8)$ & $\begin{array}{l}\text { 観察機会なし } \\
\text { 麻痺があり看護師が行う }\end{array}$ & $0(0)$ & 評価不可なし \\
\hline 入浴 & $.384 \mathrm{~ns}$ & $18(46.2)$ & 観察機会なし & $0(0)$ & 評価不可なし \\
\hline 訓練 & $.328^{*}$ & $1(2.6)$ & 観察機会なし & $0(0)$ & 評価不可なし \\
\hline 服薬 & $.325 \mathrm{~ns}$ & $6(15.4)$ & $\begin{array}{l}\text { 観察機会なし } \\
\text { 內服中かどうか知らない }\end{array}$ & $0(0)$ & 評価不可なし \\
\hline テレビ & $.434^{* *}$ & $2(5.1)$ & $\begin{array}{l}\text { 設置していない } \\
\text { 視力障害で見ることができない }\end{array}$ & $3(7.7)$ & $\begin{array}{l}\text { 設置していない } \\
\text { 見るよう促していない }\end{array}$ \\
\hline 新聞 & $.675^{* *}$ & $9(23.1)$ & $\begin{array}{l}\text { 観察機会なし } \\
\text { 視力障害で読めない } \\
\text { 失語症のため読めない } \\
\text { 入院前から読む習慣がない } \\
\text { 手元に新聞がない } \\
\text { 読むように勧めていない }\end{array}$ & $18(46.2)$ & $\begin{array}{l}\text { 促していない } \\
\text { 観察機会なし } \\
\text { 読めるかわからない } \\
\text { 視力障害のため読めない }\end{array}$ \\
\hline 挨拶 & $.086 \mathrm{~ns}$ & $0(0)$ & 評価不可なし & $0(0)$ & 評価不可なし \\
\hline 会話 & $.256 \mathrm{~ns}$ & $4(10.3)$ & 失語症で上手くできない & $2(5.1)$ & 失語症で上手く話せない \\
\hline 電話 & $.560^{*}$ & $13(33.4)$ & $\begin{array}{l}\text { 失語症で電話では話せない } \\
\text { 促していない } \\
\text { 面会時に来るため必要ない } \\
\text { 頻回に使うため, 預かっている }\end{array}$ & $24(61.5)$ & $\begin{array}{l}\text { 観察機会なし } \\
\text { 使用を促したことがない } \\
\text { 失語症で使用できない } \\
\text { よくわからない }\end{array}$ \\
\hline 手紙 & - & $25(64.1)$ & $\begin{array}{l}\text { 右片麻痺, 失語で不可 } \\
\text { 病前から習慣がない } \\
\text { 入院中のため必要ない } \\
\text { 手紙を書くことを促していない }\end{array}$ & З2 (82.1) & $\begin{array}{l}\text { 書くように促していない } \\
\text { 観察機会なし } \\
\text { 失語症や片麻痺で書けない } \\
\text { 現在の認知機能では難しい }\end{array}$ \\
\hline 行事 & $.486^{*}$ & $8(20.5)$ & $\begin{array}{l}\text { 入院中で参加できない } \\
\text { 観察機会なし }\end{array}$ & $9(23.1)$ & $\begin{array}{l}\text { 観察機会なし } \\
\text { よくわからない }\end{array}$ \\
\hline 趣味 & $.569 \mathrm{~ns}$ & $28(71.8)$ & $\begin{array}{l}\text { 麻痺のため実施不可 } \\
\text { 入院中では不可（ゴルフ等） } \\
\text { 病前から趣味がない) } \\
\text { 疲労のため趣味実施不可 }\end{array}$ & 28 (71.8) & $\begin{array}{l}\text { 入院中のため実施不可 } \\
\text { 観察機会なし } \\
\text { 病前から趣味がない } \\
\text { 麻痺のため趣味ができない } \\
\text { 趣味が何かわからない }\end{array}$ \\
\hline 問題解決 & $.552^{* *}$ & $2(5.1)$ & $\begin{array}{l}\text { 考えることができない } \\
\text { 試みたことがない, わからない }\end{array}$ & $1(2.6)$ & 観察機会なし \\
\hline
\end{tabular}

注）相関係数はSpearman の相関係数. ${ }^{* *} p<0.01,{ }^{*} p<0.05, \mathrm{~ns}$. は有意差なし.「手紙を書く」の評価については，評価可能であった対象が少な く, 相関係数の算出ができなかつた. ほ は人数 $(\%)$. 評価不可と回答した人にはその理由を尋ね, 発言内容と人数を調査した.

患者との会話状沉のインタビューを実施する等の対 応が必要であることが推測された。

\section{3. 自発性低下の評価尺度に対する臨床活用の可 能性と看護への示唆}

本研究では CAS3 を, 自発性低下の評価尺度とし て活用したが，FIM，MMSEの得点と強い負の相関 を示した。先述したように, CAS3 を活用すること で患者の日常生活の詳細な観察につながり, 軽度の 自発性低下を発見できる利点がある。しかし, 行為 遂行に際して身体機能障害（運動麻痺等）の影響に より機能的に不可能であるのか, それとも自発性低 下の影響であるのかを区別するためには, 評価者に
対し事前の訓練が必要であると推測された。CAS を 活用した自発性低下の評価報告は少ないが，四元ら (2010) は Barthel Index (BI) と CAS3 の相関関係が 強いと報告し, 本調査も四元ら（2010）の結果と類似 していた。しかし，CAS3の作成者である浜田 (2006) は, BI や FIM は日常生活の実際の行動能力そのも のを評価するものであって，日常生活行動に反映さ れる意欲状況を評価する CAS とは評価段階がまった く異なると述べている。以上より，CAS3 については， 今後も自発性を測定するための評価項目や質問内容 の検証が必要と考えられた。また,「新聞」「趣味活 動」等, 評価不可と回答される頻度の高い項目があっ た。CAS3の活用については，例えば「新聞を読む」 
の評価では新聞を持参し勧める等，評価前の状況設 定の考慮が必要であった。本研究では，CAS3 のみし か活用していないため, 今後は CAS の全スケールを 用いて自発性の評価を試みる必要がある。

\section{4. 本研究の限界と今後の課題}

本研究の限界は, 研究期間が限られていたため対 象者数が少数であり, 研究の同意確認のため, 無動 無言症に代表される最重症の自発性低下の患者が評 価対象から除外された。また，家族は面会時間が限 られるため, 看護師に比較して面会時間中に観察す ることが困難な項目があった。 今後評価の精度を高 めるためには，評価期間を延長する等の対応が必要 であろう。

\section{V. 結 論}

本研究結果として CAS3 の回答結果の合計を示す \% 評価值においては, 家族と看護師の評価に有意な 評価差を認めず，回答が類似する傾向を認めた。し かし, 評価項目別に分析した結果, 入浴や服薬など 家族の観察機会の少ない項目は, 看護師がより詳細 に観察し，コミュニケーションや，身だしなみ等の 発症前の患者の性格や生活状況が評価に影響する項 目では, 家族の方が看護師より詳細な患者評価を行っ ていた。 以上より，看護師と家族両者がお互いの意 見を検討しつつ, 自発性低下の重症度を検討するこ とが, 評価の精度を高めるために有効であると示唆 された。

謝辞：研究にご協力いただきました皆様，ご指導をいただ きました皆様に厚く御礼申し上げます。

\section{文献}

Brodaty H., Sachdev P. S., Withall A., et al. (2005): Frequency and clinical, neuropsychological and neuroimaging correlates of apathy following stroke: The Sydney stroke study, Psychol. Med., 35(12), 1707-1716.

Chen M. H., Hsieh C. L., Mao F. H., et al. (2007): Differences between patient and proxy reports in the assessment of disability after stroke, Clin. Rehabil., 21(4), 351-356.

千野直一 (1991) : FIM 医学的リハビリテーションのための 統一データセット利用の手引き（原著第 3 版), 慶應義塾 大学医学部リハビリテーション医学教室, 東京.
千野直一編著 (1997)：機能的自立度評価法 (FIM) - FIM の評価方法一, 脳卒中患者の機能評価 SIAS と FIM の実際, 52-86, シュプリンガー・ジャパン株式会社, 東京.

Folstein M. F., Folstein S. E., McHcgh P. R. (1975): “Minimental state" : A practical method for grading the cognitive state of patients for the clinician, J. Psychiatr. Res., 12(3), 189-198.

Hama S., Yamashita H., Shigenobu M., et al. (2007): Depression or apathy and functional recovery after stroke, Int. J. Geriatr. Psychiatry, 22 (10), 1046-1051.

浜田博文 (2006)：日常生活行動の意欲評価スケール，標準 意欲評価法, 142-146, 新興医療出版社, 東京.

加藤元一郎 (2006) : 標準意欲評価法 (CAS) について, 標 準意欲評価法，129-130，新興医療出版社，東京.

窪田正大, 浜田博文, 岩瀬義昭, 他 (2001) : 脳血管障害患 者のリハビリテーションにおける意欲一自発性（Will and Spontaneity) スケールの作成一, 鹿児島大学医学部保健 学科紀要, 11(2), 167-173.

Malec J. F., Machulda M. M., Moessner A. M. (1997): Differing problem perceptions of staff, survivors, and significant others after brain injury, J. Head Trauma Rehabil., 12(3), 1-13.

Marin R. S., Biedrzycki R. C., Firinciogullari S. (1991): Reliability and validity of the apathy evaluation scale, Psychiatry Res., 38(2), 143-162.

水野勝弘, 大田哲生 (2005)：リハに打けるアウトカム評 価尺度, FIM, Barthel Index, J. Clin. Rehabil., 14(2), 174-179.

森悦朗, 三谷洋子, 山鳥重 (1985) : 神経疾患患者における 日本版 Mini-Mental State テストの有用性, 神経心理学, $1(2), 82-90$.

日本高次脳機能障害学会編 (2006) : 標準注意検査法 - 標準 意欲評価法, 新興医学出版社, 東京.

布谷芳久, 椿原彰夫 (1994) : 発動性障害の評価とリハビリ テーション, 脳と精神の医学, 5(3), 331-336.

岡田和悟，小林祥泰，青木耕，他（1998）：やる気スコアを 用いた脳卒中後の意欲低下の評価, 脳卒中, 20, 318-323.

大東祥孝 (2008) : 意欲・発動性の障害, よくわかる失語症 セラピーと認知リハビリテーション, 537-543, 永井書店, 大阪.

Østbye T., Tyas S., McDowell I., et al. (1997): Reported activities of daily living: Agreement between elderly subjects with and without dementia and their caregivers, Age and Agings, 26 (2), 99-106.

四元孝道, 窪田正大, 山内愛, 他 (2010) : 脳血管障害患者 の意欲障害と ADL 自立度の関係および損傷部位に関する 研究, 作業療法ジャーナル, 44(5), 411-414.

涌井富美子, 園田茂, 赤星和人, 他 (1993)：脳障害者に対 する新しい自発性評価表 (S-Score) 使用の試み, 総合リ八, 21 (6), 507-510.

Williams A. M., Dahl C. W. (2002): Patient and caregiver perceptions of stroke survivor behavior: A comparison, Rehabil. Nurs., 27 (1), 19-24. 